\title{
KETERKAITAN ASAS TERJANGKAU DARI PENDAFTARAN TANAH DENGAN PELAYANAN PENDAFTARAN TANAH BERUPA PELAYANAN PENDAFTARAN TANAH UNTUK PERTAMA KALI TERHADAP PIHAK TERTENTU
}

\author{
Mira Novana Ardani \\ Fakultas Hukum Universitas Diponegoro \\ Jl. Prof. Soedarto,SH. Tembalang, Semarang \\ email : miranovana@yahoo.com
}

\begin{abstract}
The series of land registration activities requires expenditures in the form of tariffs charged at each stage. The principle that we can associate with the provisions of Article 9 paragraph (4) of the UUPA is an affordable principle, in the government regulation the costs related to land registration are regulated, provided that the people who are not able to be released are paid for the fees. we can also find it in Government Regulation Number 128 of 2015 concerning Types and Rates of Types of Non-Tax State Revenues that Apply to the Ministry of Agrarian and Spatial Planning / National Land Agency. How is the affordable principle of land registration with the land registration service in the form of the first land registration service for certain parties. This study uses a normative juridical approach. Affordable principles in land registration can be seen in Government Regulation No. 128 of 2015, Article 22 and Article 24, which will certainly ease the burden on certain designated parties, so that they can reach those who need, especially the poor.
\end{abstract}

Keywords: Affordable Principle, Land Registration, First Time, Parties

\begin{abstract}
Abstrak
Rangkaian kegiatan pendaftaran tanah memerlukan pengeluaran berupa tarif yang dikenakan pada masing-masing tahapannya. Asas yang dapat kita kaitkan dengan ketentuan Pasal 9 ayat (4) UUPA adalah asas terjangkau,dalam peraturan pemerintah diatur biaya-biaya yang bersangkutan dengan pendaftaran tanah, dengan ketentuan bahwa rakyat yang tidak mampu dibebaskan dari pembayaran biaya-biaya tersebut.Peraturan pemerintah yang dimaksud pun dapat kita jumpai pada Peraturan Pemerintah Nomor 128 Tahun 2015 tentang Jenis dan Tarif Atas Jenis Penerimaan Negara Bukan Pajak Yang Berlaku Pada Kementerian Agraria dan Tata Ruang/Badan Pertanahan Nasional. Bagaimana keterkaitan asas terjangkau dari pendaftaran tanah dengan pelayanan pendaftaran tanah berupa pelayanan pendaftaran tanah untuk pertama kali terhadap pihak tertentu. Penelitian ini menggunakan pendekatan yuridis normatif. Asas terjangkau dalam pendaftaran tanah dapat dilihat penerapannya dalam Peraturan Pemerintah Nomor 128 Tahun 2015, Pasal 22 dan Pasal 24, tentu akan meringankan beban bagi pihak tertentu yang ditunjuk tersebut, sehingga dapat menjangkau pihak-pihak yang memerlukan, khususnya masyarakat tidak mampu.
\end{abstract}


Kata Kunci: Asas Terjangkau, Pendaftaran Tanah, Pertama kali, Pihak Tertentu

\section{A. Pendahuluan}

Kepastian hukum terhadap kepemilikan suatu hak atas tanah tentu sangat diinginkan bagi pemegang hak. Usaha yang menuju ke arah kepastian mengenai hak atas tanah tersebut dapat dilihat dari aturan yang ada. Ketentuan yang terdapat dalam Undang-Undang Pokok Agraria (UUPA), yakni Pasal 19, dalam ayat (1) nya mengatakan bahwa untuk menjamin kepastian hukum oleh pemerintah diadakan pendaftaran tanah di seluruh wilayah Republik Indonesia menurut ketentuan-ketentuan yang diatur dengan peraturan pemerintah.

Isi Pasal 19 tersebut menunjuk kepada pemerintah sebagai suatu instruksi, agar di seluruh wilayah Indonesia diadakan pendaftaran tanah yang bertujuan untuk menjamin kepastian hukum. Hal ini berbeda dengan ketentuan yang terdapat dalam Pasal 23, 32, dan 38 UUPA ditujukan kepada para pemegang hak yang bersangkutan, dengan tujuan agar mereka dapat memperoleh kepastian tentang haknya, maka hak atas tanah yang dimiliki harus didaftar.

Adapun pendaftaran itu akan diselenggarakan dengan mengingat pada kepentingan serta keadaan negara dan masyarakat, keperluan lalu-lintas sosial ekonomi dan kemungkinan-kemungkinannya dalam bidang personil dan peralatannya. Oleh karena itu, maka akan didahulukan penyelenggaraannya di kota-kota untuk lambat laun meningkat pada kadaster yang meliputi seluruh wilayah negara. ${ }^{1}$

Kegiatan pendaftaran tanah, sesuai dengan Pasal 19 ayat (2), meliputi pengukuran, perpetaan, dan pembukuan tanah; pendaftaran hak-hak atas tanah dan peralihan hak-hak tersebut; pemberian surat-surat tanda bukti hak, yang berlaku sebagai alat pembuktian yang kuat. Apabila dilihat dari pelaksanaan pendaftaran tanahnya, menurut Pasal 11 Peraturan Pemerintah Nomor 24 Tahun 1997 tentang Pendaftaran Tanah, terdiri dari dua, yakni kegiatan pendaftaran tanah untuk pertama kali, dan pemeliharaan data pendaftaran tanah.

Sertipikat merupakan alat bukti yang dapat digunakan oleh pemilik hak atas tanah yang bersangkutan untuk membuktikan bahwa tanah tersebut adalah miliknya. Sertipikat hak atas tanah merupakan alat pembuktian yang kuat

\footnotetext{
${ }^{1}$ Boedi Harsono, Hukum Agraria Indonesia, Sejarah Pembentukan Undang-Undang Pokok Agraria Isi Dan Pelaksanaannya, Djambatan, Jakarta, 2008, hal. 582
} 
sebagaimana dinyatakan dalam Pasal 32 ayat (1) Peraturan Pemerintah Nomor 24 Tahun 1997 yang menyebutkan "Selama belum dibuktikan yang sebaliknya, data fisik dan data yuridis yang dicantumkan dalam sertipikat harus diterima sebagai data yang benar, baik dalam perbuatan hukum sehari-hari maupun dalam sengketa di pengadilan sepanjang data tersebut sesuai dengan apa yang tercantum dalam surat ukur dan buku tanah yang bersangkutan". Sehingga, sertipikat bukan merupakan tanda bukti yang mutlak.

Pendaftaran tanah dilaksanakan berdasarkan asas sederhana, aman, terjangkau, mutakhir, dan terbuka. Ketentuan mengenai asas tersebut dapat kita jumpai dalam Peraturan Pemerintah Nomor 24 Tahun 1997 tentang Pendaftaran Tanah. Salah satu asas yang dapat kita kaitkan dengan ketentuan yang terdapat dalam Pasal 9 UUPA ayat (4) adalah asas terjangkau, yang mana disebutkan bahwa dalam peraturan pemerintah diatur biaya-biaya yang bersangkutan dengan pendaftaran termaksud dalam ayat (1), dengan ketentuan bahwa rakyat yang tidak mampu dibebaskan dari pembayaran biaya-biaya tersebut.

Peraturan pemerintah yang dimaksud pun dapat kita jumpai pada Peraturan Pemerintah Nomor 128 Tahun 2015 tentang Jenis dan Tarif Atas Jenis Penerimaan Negara Bukan Pajak Yang Berlaku Pada Kementerian Agraria dan Tata Ruang/Badan Pertanahan Nasional. Salah satu pertimbangan dikeluarkannya peraturan pemerintah tersebut untuk meringankan beban masyarakat dan upaya menggerakkan ekonomi nasional.

Berdasarkan hal diatas, maka permasalahan yang timbul dalam tulisan ini, bagaimana keterkaitan asas terjangkau dari pendaftaran tanah dengan pelayanan pendaftaran tanah berupa pelayanan pendaftaran tanah untuk pertama kali terhadap pihak tertentu (Peraturan Pemerintah Nomor 128 Tahun 2015 tentang Jenis dan Tarif Atas jenis Penerimaan Negara Bukan Pajak yang berlaku pada Kementerian Agraria dan Tata Ruang/ Badan Pertanahan Nasional)?

\section{B. Metode Penelitian}

Penelitian ini menggunakan pendekatan yuridis normatif. Penelitian yuridis normatif memiliki makna penelitian yang difokuskan untuk mengkaji penerapan kaidah-kaidah atau norma-norma dalam hukum positif. ${ }^{2}$ Sedangkan

\footnotetext{
2 Johnny Ibrahim, 2006, Teori dan Metodologi Penelitian Hukum Normatif, Malang: Bayumedia Publishing, hlm. 295.
} 
yuridis normatif itu sendiri memiliki pengertian pendekatan yang menggunakan konsepsi legis positivis. Konsep ini memandang hukum identik dengan norma-norma tertulis yang dibuat dan diundangkan oleh lembaga atau pejabat yang berwenang. Konsepsi ini memandang hukum sebagai suatu sistem normatif yang bersifat mandiri, tertutup dan terlepas dari kehidupan masyarakat yang nyata. ${ }^{3}$

Jenis data yang dipergunakan yakni data primer, sekunder, maupun tertier. Data primer yaitu berupa peraturan perundang-undangan, baik Undang-Undang Pokok Agraria maupun peraturan perundang-undangan lainnya. Selain itu penggunaan data sekunder juga digunakan, yaitu diperoleh melalui studi kepustakaan, studi dokumenter maupun aturan-aturan hukum dalam peraturan perundang-undangan yang berfungsi untuk menunjang kelengkapan data primer. ${ }^{4}$ Bahan hukum tertier, yakni bahan yang memberikan petunjuk maupun penjelasan terhadap hukum primer dan sekunder; contohnya adalah kamus, ensiklopedia, dan seterusnya.

Metode pengumpulan data dalam penelitian ini dilakukan dengan studi pustaka, yaitu suatu cara pengumpulan data dengan melakukan penelusuran dan menelaah bahan pustaka (literatur, hasil penelitian, majalah ilmiah, buletin ilmiah, jurnal ilmiah, dan sebagainya). Hasil penelitian disajikan dalam bentuk uraianuraian yang tersusun secara sistematis, artinya data sekunder yang diperoleh akan dihubungkan satu dengan yang lain disesuaikan dengan permasalahan yang diteliti, sehingga secara keseluruhan merupakan satu kesatuan yang utuh sesuai dengan kebutuhan penelitian.

Untuk menganalisis data yang diperoleh, akan digunakan metode analisis normatif, merupakan cara menginterpretasikan dan mendiskusikan bahan hasil penelitian berdasarkan pada pengertian hukum, norma hukum, teori-teori hukum serta doktrin yang berkaitan dengan pokok permasalahan. Norma hukum diperlukan sebagai premis mayor, kemudian dikorelasikan dengan fakta-fakta yang relevan (legal facts) yang dipakai sebagai premis minor dan melalui proses silogisme akan diperoleh kesimpulan (conclution) terhadap permasalahannya.

\footnotetext{
${ }^{3}$ Ronny Hanitijo Soemitro, 1988, Metodologi Penelitian Hukum dan Jurimetri, Jakarta: Ghalia Indonesia, hlm. 13-14

${ }^{4}$ Op.Cit,hlm.9
} 
Sesuai dengan ketentuan yang terdapat dalam Pasal 19 UUPA, Pendaftaran tanah yang dilaksanakan di Indonesia merupakan pendaftaran tanah dalam rangka "Rechts kadaster", yaitu pendaftaran tanah yang tujuannya adalah dalam rangka untuk memberikan kepastian hukum dan perlindungan hukum kepada pemegang hak atas tanah. Bertugas untuk mengadakan pendaftaran tanah di seluruh wilayah Republik Indonesia yaitu pemerintah, dalam hal ini yakni Badan Pertanahan Nasional.

Hal tersebut juga berkaitan dengan Pasal 2 UUPA, mengenai Hak Menguasai dari Negara. Negara dalam hal ini mempunyai tugas untuk menyelenggarakan administrasi pertanahan dalam lingkup tugas administrasi negara. Tugas pemerintahan di bidang keagrariaan atau pertanahan, antara lain: ${ }^{5}$

a. Tugas penyelenggaraan pengelolaan agraria atau pertanahan dan mengatur (dengan menyiapkan proses legislasi dalam rangka regulasi dan penetapan kebijakan publik).

b. Tugas menetapkan (beschikking) secara individual, mengeluarkan ketetapanketetapan yang berisi kebijakan publik serta pengaturan (legislasi dan regulasi) ketentuan hubungan-hubungan hukum antara masyarakat dengan tanah pada umumnya.

c. Tugas menetapkan (beschikking) dan mengatur (regulating) mengenai tata cara atau prosedur ketatalaksanaan administrasi pendaftaran tanah untuk menciptakan kepastian hukum atas tanah.

d. Tugas dan kewenangan untuk memungut uang pemasukan kepada negara (recognitie) yang merupakan kewajiban bagi warga masyarakat penerima hak atas tanah sebagai tanda telah terciptanya hubungan-hubungan hukum. Tugas dan kewenangan ini antara lain:

a). Kewajiban pembayaran uang pemasukan kepada negara, sebagai akibat dari penetapan hak karena pemberian hak baru, perpanjangan jangka waktu, perubahan atau pembaharuan hak atas tanah;

b). Kewajiban pembayaran biaya administrasi (leges), canon dan cijn atau uang wajib tahunan pada penerima hak guna uasaha atas tanah untuk penggunaan perusahaan perkebunan besar.

\footnotetext{
${ }^{5}$ Rusmadi Murad, 2013, Administrasi Pertanahan Pelaksanaan Hukum Pertanahan Dalam Praktek, Bandung, Mandar Maju, hlm.4
} 
Pengertian pendaftaran tanah menurut Peraturan Pemerintah Nomor 24 Tahun 1997 adalah rangkaian kegiatan yang dilakukan oleh pemerintah secara terusmenerus, berkesinambungan dan teratur, meliputi pengumpulan, pengolahan, pembukuan, dan penyajian serta pemeliharaan data fisik dan data yuridis, dalam bentuk peta dan daftar, mengenai bidang-bidang tanah dan satuansatuan rumah susun, termasuk pemberian surat tanda bukti haknya bagi bidangbidang tanah yang sudah ada haknya dan hak milik atas satuan rumah susun serta hak-hak tertentu yang membebaninya.

Pelaksanaan pendaftaran tanah meliputi kegiatan pendaftaran tanah pertama kali (initial registration), dan pemeliharaan data pendaftaran tanah (maintenance). Pendaftaran tanah pertama kali adalah kegiatan pendaftaran yang dilakukan terhadap obyek pendaftaran tanah yang belum didaftar berdasarkan Peraturan Pemerintah Nomor 10 tahun 1961 tentang Pendaftaran Tanah atau Peraturan Pemerintah Nomor 24 Tahun 1997. Sedangkan pemeliharaan data pendaftaran tanah adalah kegiatan pendaftaran tanah untuk menyesuaikan data fisik dan data yuridis dalam peta pendaftaran, daftar tanah, daftar nama, surat ukur, buku tanah, dan sertipikat dengan perubahan-perubahan yang terjadi kemudian. ${ }^{6}$

Sesuai dengan isi yang terdapat dalam ketentuan Peraturan Pemerintah Nomor 24 Tahun 1997, kegiatan pendaftaran tanah untuk pertama kali meliputi: a. Pengumpulan dan pengolahan data fisik; b. Pembuktian hak dan pembukuannya; c. Penerbitan sertipikat; d. Penyajian data fisik dan data yuridis; e. Penyimpanan daftar umum dan dokumen. Pendaftaran tanah untuk pertama kali dilaksanakan melalui pendaftaran tanah secara sistematik dan pendaftaran tanah secara sporadik. Pendaftaran tanah secara sistematik dilaksanakan atas prakarsa Badan Pertanahan Nasional yang didasarkan atas suatu rencana kerja jangka panjang, dan rencana tahunan yang berkesinambungan. Pelaksanaannya dilakukan di wilayahwilayah yang belum ditunjuk oleh menteri. ${ }^{7}$

Pada wilayah-wilayah yang belum ditunjuk sebagai wilayah pendaftaran tanah secara sistematik, pendaftarannya dilaksanakan secara sporadik. Pendaftaran

\footnotetext{
${ }^{6}$ Boedi Harsono, Op.cit, hlm.475

${ }^{7}$ Ibid, hlm.487
} 
tanah secara sporadik dilaksanakan atas permintaan pihak yang berkepentingan, yaitu pihak yang berhak atas obyek pendaftaran tanah yang bersangkutan. ${ }^{8}$

Pelaksanaan pendaftaran tanah, sesuai dengan Pasal 2 Peraturan Pemerintah Nomor 24 tahun 1997 berdasarkan atas asas sederhana, asas aman, asas terjangkau, asas mutakhir, serta asas terbuka. Terdapat hubungan antara asas terjangkau dengan ketentuan yang terdapat dalam Pasal 19 ayat (4) UUPA. Asas terjangkau ini dimaksudkan keterjangkauan bagi pihak-pihak yang memerlukan, khususnya dengan memperhatikan kebutuhan dan kemampuan golongan ekonomi lemah. Pelayanan yang diberikan dalam rangka penyelenggaraan pendaftaran tanah harus bisa terjangkau oleh pihak yang memerlukan. Selain itu, terdapat Peraturan Pemerintah Nomor 128 Tahun 2015 tentang Jenis dan Tarif Atas Jenis Penerimaan Negara Bukan Pajak Yang Berlaku Pada Kementerian Agraria dan Tata Ruang/Badan Pertanahan Nasional.

\section{Hasil dan Pembahasan}

Keterkaitan Asas Terjangkau Dari Pendaftaran Tanah Dengan Pelayanan Pendaftaran Tanah Berupa Pelayanan Pendaftaran Tanah Untuk Pertama Kali Terhadap Pihak Tertentu (Peraturan Pemerintah Nomor 128 Tahun 2015 Tentang Jenis Dan Tarif Atas Jenis Penerimaan Negara Bukan Pajak Yang Berlaku Pada Kementerian Agraria dan Tata Ruang/Badan Pertanahan Nasional). Pendaftaran tanah di seluruh wilayah Negara Republik Indonesia diselenggarakan oleh pemerintah Indonesia, dalam rangka mengatur hubungan hukum antara subyek dan obyek bidang-bidang tanah. ${ }^{9}$ Untuk menjamin kepastian hukum oleh pemerintah diadakan pendaftaran tanah di seluruh wilayah Republik Indonesia menurut ketentuan-ketentuan yang diatur dengan peraturan pemerintah. Hal tersebut terdapat dalam Pasal 19 ayat (1) UUPA. Penyelenggaraan pendaftaran tanah tersebut merupakan instruksi yang diberikan kepada pemerintah, dalam hal ini Badan Pertanahan Nasional, yang pelaksanaannya ada pada Kantor Pertanahan.

Amanah yang disampaikan pada Pasal 19 UUPA tersebut, salah satunya penyelenggaraan pendaftaran tanah dilakukan di seluruh wilayah

\footnotetext{
${ }^{8}$ Ibid

${ }^{9}$ Prama Widianugraha, : http://jurnal.fh.unpad.ac.id/index.php/jbmh/issue/archive, Tinjauan Normatif Pendaftaran Tanah Sistematis Lengkap Dikaitkan Pembentukan Aturan Peraturan Perundang-Undangan, Jurnal Bina Mulia Hukum, Volume 3, Nomor 2, Maret 2019
} 
Republik Indonesia. Terdapat beberapa kegiatan pendaftaran tanah, khususnya kegiatan pendaftaran tanah untuk pertama kali, yang mana tentu saja ini akan mempengaruhi pada pembebanan biaya pendaftaran tanah itu sendiri. Ketentuan mengenai biaya-biaya apa saja yang dibebankan dalam pendaftaran tanah, dalam hal ini pendaftaran tanah pertama kali, dapat kita temui dalam Peraturan Pemerintah Nomor 128 Tahun 2015 Tentang Jenis Dan Tarif Atas Jenis Penerimaan Negara Bukan Pajak Yang Berlaku Pada Kementerian Agraria dan Tata Ruang/Badan Pertanahan Nasional.

Pasal 1 Peraturan Pemerintah Nomor 128 Tahun 2015, mengatur jenis penerimaan negara bukan pajak yang berlaku pada Kementerian Agraria dan Tata Ruang/Badan Pertanahan Nasional adalah penerimaan yang salah satunya berasal dari pelayanan pendaftaran tanah. Jenis Penerimaan Negara Bukan Pajak yang berasal dari pelayanan pendaftaran tanah menurut Pasal 15, meliputi pelayanan pendaftaran tanah untuk pertama kali, dan pelayanan pemeliharaan data pendaftaran tanah. Dalam penjelasannya, pendaftaran tanah untuk pertama kali adalah kegiatan pendaftaran tanah yang dilakukan terhadap objek pendaftaran tanah yang belum didaftar, sedangkan pemeliharaan data pendaftaran tanah adalah kegiatan pendaftaran tanah untuk menyesuaikan data fisik dan data yuridis dalam peta pendaftaran, daftar tanah, daftar nama, surat ukur, buku tanah, dan sertipikat dengan perubahan yang terjadi kemudian.

Mengenai tarif pelayanan pendaftaran tanah untuk pertama kali berupa pelayanan pendaftaran diatur dalam Pasal 16, yaitu: a. Keputusan Perpanjangan Hak Atas Tanah untuk Hak Guna Usaha, Hak Guna Bangunan, atau Hak Pakai Berjangka Waktu; b. Keputusan Pembaruan Hak Atas Tanah untuk Hak Guna Usaha, Hak Guna Bangunan, atau Hak Pakai Berjangka Waktu; dihitung berdasarkan rumus $\mathrm{T}=(2 \% \mathrm{x}$ Nilai Tanah $)+\mathrm{Rp} 100.000,00$. Sedangkan tarif pelayanan pemeliharaan data pendaftaran tanah berupa pelayanan pendaftaran pemindahan peralihan hak atas tanah untuk perorangan dan Badan Hukum, dihitung berdasarkan rumus $\mathrm{T}=(1 \% \mathrm{x}$ Nilai Tanah $)+\mathrm{Rp} 50.000,00$. Yang dimaksud dengan "Nilai Tanah" adalah nilai pasar (market value) yang ditetapkan oleh Kementerian Agraria dan Tata Ruang/Badan Pertanahan Nasional dalam peta zona nilai tanah yang disahkan oleh Kepala Kantor Pertanahan untuk tahun 
berkenaan dan untuk wilayah yang belum tersedia peta zona nilai tanah digunakan Nilai Jual Objek Pajak atas tanah pada tahun berkenaan.

Ketentuan dalam Pasal 17 ayat (1) menyebutkan bahwa jenis dan tarif atas jenis Penerimaan Negara Bukan Pajak, salah satunya dalam pelayanan pendaftaran tanah, ditetapkan dalam lampiran Peraturan Pemerintah Nomor 128 Tahun 2015. Ayat (2) dalam pasal tersebut mengatakan bahwa jenis dan tarif atas jenis Penerimaan Negara Bukan Pajak sebagaimana dimaksud pada ayat (1) tidak termasuk jenis pelayanan pendaftaran tanah yang diatur dalam Pasal 16.

Jenis dan tarif atas jenis Penerimaan Negara Bukan Pajak yang berlaku Pada Kementerian Agraria dan Tata Ruang/Badan Pertanahan Nasional sesuai lampiran yang tertera dalam Peraturan pemerintah Nomor 128 Tahun 2015 terkait pada layanan pendaftaran tanah untuk Pelayanan Pendaftaran Tanah untuk Pertama Kali:

\begin{tabular}{|c|c|c|c|}
\hline No & $\begin{array}{c}\text { JENIS PENERIMAAN } \\
\text { NEGARA BUKAN PAJAK } \\
\end{array}$ & SATUAN & TARIF \\
\hline 1 & $\begin{array}{l}\text { Pelayanan Pendaftaran Penegasan } \\
\text { Konversi atau Pengakuan Hak }\end{array}$ & Per bidang & Rp 50.000,00 \\
\hline 2 & $\begin{array}{l}\text { Pelayanan Pendaftaran Keputusan } \\
\text { Pemberian Hak Atas Tanah untuk: } \\
\text { a. Perorangan } \\
\text { b. Badan Hukum }\end{array}$ & $\begin{array}{l}\text { Perbidang } \\
\text { Per bidang }\end{array}$ & $\begin{array}{l}\text { Rp } 50.000,00 \\
\operatorname{Rp} 100.000,00\end{array}$ \\
\hline 3 & $\begin{array}{l}\text { Pelayanan Pendaftaran Keputusan } \\
\text { perpanjangan Hak Atas Tanah } \\
\text { untuk Hak Guna Bangunan dan } \\
\text { Hak Pakai di atas Hak Pengelolaan }\end{array}$ & Per bidang & Rp 50.000,00 \\
\hline 4 & $\begin{array}{l}\text { Pelayanan Pendaftaran Keputusan } \\
\text { pembaruan Hak Atas Tanah untuk } \\
\text { Hak Guna Bangunan dan Hak Pakai } \\
\text { di atas Hak Pengelolaan }\end{array}$ & Per bidang & Rp 50.000,00 \\
\hline 5 & $\begin{array}{l}\text { Pelayanan Pendaftaran Hak Milik } \\
\text { Atas Satuan Rumah Susun } \\
\text { a. Bersubsidi (berdasarkan }\end{array}$ & Per unit & Rp 50.000,00 \\
\hline & $\begin{array}{l}\text { penetapan Kementerian Perumahan } \\
\text { Rakyat/ Kementerian Pekerjaan } \\
\text { Umum dan Perumahan Rakyat) } \\
\text { b. Non Subsidi }\end{array}$ & Per unit & Rp 100.000,00 \\
\hline 6 & $\begin{array}{l}\text { Pelayanan Pendaftaran Hak Guna } \\
\text { Ruang Atas Tanah, Ruang Bawah } \\
\text { Tanah, dan Ruang Perairan }\end{array}$ & Per bidang & Rp 50.000,00 \\
\hline 7 & $\begin{array}{l}\text { Pendaftaran Perubahan Hak: } \\
\text { a. Hak Guna Bangunan atau Hak }\end{array}$ & Per bidang & Rp 50.000,00 \\
\hline & Pakai menjadi Hak Milik & $\begin{array}{l}\text { Per bidang } \\
\text { Per bidang }\end{array}$ & $\begin{array}{l}\text { Rp } 50.000,00 \\
\text { Rp 50.000,00 } \\
\end{array}$ \\
\hline
\end{tabular}



b. Hak Pakai menjadi Hak Guna Per bidang
Bangunan
c. Hak Guna Bangunan menjadi
Hak Pakai
d. Hak Milik menjadi Hak Guna
Bangunan atau Hak Pakai

Tabel 1. Sumber: Lampiran Peraturan Pemerintah Nomor 128 Tahun 2015 Tentang Jenis Dan Tarif Atas Jenis Penerimaan Negara Bukan Pajak Yang Berlaku Pada Kementerian Agraria dan Tata Ruang/Badan Pertanahan Nasional.

Sesuai Pasal 26, jenis Penerimaan Negara Bukan Pajak yang berlaku pada Kementerian Agraria dan Tata Ruang/Badan Pertanahan Nasional mempunyai tarif dalam satuan rupiah dan persentase. Seluruh Penerimaan Negara Bukan Pajak yang berlaku pada Kementerian Agraria dan Tata Ruang/Badan Pertanahan Nasional wajib disetor langsung secepatnya ke kas negara. Hal ini diatur dalam Pasal 27.

Berdasarkan uraian diatas, penghitungan tarif khususnya mengenai pelayanan pendaftaran tanah untuk pertama kali yang dikenakan terhadap pemohon antara lain tarif yang terdapat di dalam Pasal 16 Peraturan pemerintah Nomor 128 Tahun 2015 yang terdiri dari keputusan perpanjangan Hak Atas Tanah untuk Hak Guna Usaha, Hak Guna Bangunan, atau Hak Pakai berjangka waktu, serta keputusan pembaruan Hak Atas Tanah untuk Hak Guna Usaha, Hak Guna Bangunan, atau Hak Pakai berjangka waktu. Selain biaya tersebut, terdapat pula tarif dalam lampiran Peraturan Pemerintah Nomor 128 Tahun 2015, yang sesuai dengan isi Pasal 17. Tarif tersebut dapat pula belum termasuk mengenai tarif kegiatan pendaftaran tanah untuk pertama kali, karena jika dilihat dalam lampiran Peraturan pemerintah Nomor 128 Tahun 2015, terdapat jenis Penerimaan Negara Bukan Pajak yang berasal dari pelayanan survei, pengukuran, dan pemetaan.

Kegiatan pendaftaran tanah untuk pertama kali menurut Pasal 12 Peraturan Pemerintah Nomor 24 Tahun 1997 tentang Pendaftaran Tanah, meliputi: a. Pengumpulan dan pengolahan data fisik; b. Pembuktian hak dan pembukuannya; c. Penerbitan sertipikat; d. Penyajian data fisik dan data yuridis; e. Penyimpanan daftar umum dan dokumen. Untuk keperluan pengumpulan dan pengolahan data 
fisik dilakukan kegiatan pengukuran dan pemetaan. Kegiatan pengukuran dan pemetaan meliputi: pembuatan peta dasar pendaftaran, penetapan batas bidangbidang tanah, pengukuran dan pemetaan bidang-bidang tanah dan pembuatan peta pendaftaran, pembuatan daftar tanah, pembuatan surat ukur.

Melihat jenis dan tarif atas jenis Penerimaan Negara Bukan Pajak yang berlaku pada Kementerian Agraria Dan Tata Ruang/Badan Pertanahan Nasional khususnya terkait pendaftaran tanah untuk pertama kali, tentu tidak sedikit biaya yang dikeluarkan oleh pemohon, terlebih jika si pemohon tersebut memiliki bidang tanah yang luas, serta lokasi yang strategis. Kondisi perekonomian masyarakat di Indonesia tidaklah sama. Pada sisi yang lain, yakni dalam Pasal 19 ayat (4) UUPA, dikatakan dalam peraturan pemerintah diatur biaya-biaya yang bersangkutan dengan pendaftaran, dengan ketentuan bahwa rakyat yang tidak mampu dibebaskan dari pembayaran biaya-biaya tersebut.

Senada dengan asas yang dimiliki oleh pendaftaran tanah itu sendiri, yakni asas terjangkau, maka pendaftaran tanah dimaksudkan keterjangkauan bagi pihakpihak yang memerlukan, khususnya dengan memperhatikan kebutuhan dan kemampuan golongan ekonomi lemah. Pelayanan yang diberikan dalam rangka penyelenggaraan pendaftaran tanah harus bisa terjangkau oleh pihak yang memerlukan. ${ }^{10}$

Asas terjangkau tersebut nampak pada aturan yang terdapat dalam Peraturan Pemerintah Nomor 128 Tahun 2015. Pasal 22 ayat (1) Peraturan Pemerintah Nomor 128 Tahun 2015 mengatur bahwa terhadap pihak tertentu dapat dikenakan tarif sebesar Rp.0,00 (nol rupiah) dari tarif atas jenis Penerimaan Negara Bukan Pajak berupa:

a. Pelayanan pengukuran dan pemetaan batas bidang tanah;

b. Pelayanan pemeriksaan tanah oleh panitia A atau pelayanan pemeriksaan tanah oleh petugas konstatasi; dan/atau

c. Pelayanan pendaftaran tanah berupa pelayanan pendaftaran tanah untuk pertama kali.

Pihak tertentu tersebut disebutkan dalam ayat (2) nya, antara lain:

a. Masyarakat tidak mampu;

${ }^{10}$ Urip Santoso, 2012, Hukum Agraria Kajian Komprehensif, Jakarta: Kencana, hlm. 291 
b. Masyarakat yang termasuk dalam program pemerintah bidang perumahan sederhana;

c. Badan hukum yang bergerak di bidang keagamaan dan sosial yang penggunaan tanahnya untuk peribadatan, pesantren, panti asuhan, panti jompo, cagar budaya, situs/tempat ziarah;

d.Veteran, pensiunan PNS, Purnawirawan TNI, purnawirawan POLRI dan suami/istri/janda/duda veteran/pensiunan PNS/purnawirawan TNI/purnawirawan POLRI;

e. Instansi Pemerintah dan Pemerintah Daerah, untuk melaksanakan tugas dan fungsinya dan tidak bersifat profit;

f. Wakif; atau

g. Masyarakat Hukum Adat.

Kategori masyarakat tidak mampu, sesuai dengan penjelasan yang terdapat pada Pasal 22 ayat (2) adalah perorangan yang besar penghasilannya per bulan dibawah Upah Minimum yang berlaku pada masing-masing Kabupaten/Kota yang dibuktikan dengan surat keterangan dari Ketua RT/RW setempat dan diketahui oleh Lurah, Kepala Desa, atau nama lainnya. Sedangkan yang dimaksud program pemerintah bidang perumahan sederhana adalah program pemerintah untuk menyediakan rumah bagi masyarakat tidak mampu/masyarakat berpenghasilan rendah.

Selain pihak tertentu tersebut, terdapat pula pihak tertentu lainnya yang dikenakan tarif hanya sebesar 50\% (lima puluh persen) dari tarif atas jenis Penerimaan Negara Bukan Pajak. Pihak tertentu tersebut antara lain:

a. PNS, Prajurit TNI, Anggota POLRI dan Suami/Istri PNS/TNI/POLRI;

b. BUMN/BUMD;

c. Badan yang mendapat penugasan khusus dari Pemerintah; dan

d. Badan hukum swasta selaku pengelola maupun pengguna Kawasan Industri atau Kawasan Ekonomi Khusus.

Pihak tertentu yang dikenakan tarif hanya sebesar 50\% (lima puluh persen) dari tarif atas jenis Penerimaan Negara Bukan Pajak tersebut diatur dalam Pasal 24 Peraturan Pemerintah Nomor 128 Tahun 2015 berupa:

a. Tarif pelayanan pengukuran dan pemetaan batas bidang tanah; 
b. Pelayanan Pemeriksaan Tanah oleh panitia A atau pelayanan pemeriksaan tanah oleh petugas konstatasi; dan/atau

c. Pelayanan pendaftaran tanah berupa pelayanan pendaftaran tanah untuk pertama kali.

Hal tersebut dilakukan dengan sebab seperti yang tertuang dalam penjelasan umum Peraturan Pemerintah Nomor 128 Tahun 2015, yakni merupakan upaya dari pemerintah menggerakkan ekonomi nasional melalui berbagai paket kebijakan ekonomi, antara lain melindungi masyarakat berpendapatan rendah dan menggerakan ekonomi pedesaan. Pelaksanaannya dengan meringankan beban masyarakat melalui penurunan tarif atau biaya pengurusan hak atas tanah. Dalam Peraturan Pemerintah Nomor 128 Tahun 2015, yang mana aturan ini merubah aturan yang sebelumnya yakni Peraturan Pemerintah Nomor 13 Tahun 2010 tentang Jenis Dan Tarif Atas Jenis Penerimaan Negara Bukan Pajak yang berlaku pada Badan Pertanahan Nasional, yakni menyempurnakan pengaturan terkait pihak tertentu. Salah satu subjek pihak tertentu yakni masyarakat tidak mampu, mendapatkan insentif berupa Rp.0,- (nol rupiah) untuk pensertipikatan tanah pertama kali berupa pengukuran batas bidang tanah, pemeriksaan tanah panitia A dan pendaftaran tanah pertama kali.

\section{Simpulan}

Berdasarkan uraian di atas, maka dapat disimpulkan bahwa Asas terjangkau dalam pendaftaran tanah dapat dilihat penerapannya dalam Peraturan Pemerintah Nomor 128 Tahun 2015 tentang Jenis Dan Tarif Atas Jenis Penerimaan Negara Bukan Pajak Yang Berlaku Pada Kementerian Agraria Dan Tata Ruang/Badan Pertanahan Nasional. Adanya peraturan yang terdapat dalam Pasal 22 dan Pasal 24 tentu akan meringankan beban bagi pihak tertentu yang ditunjuk tersebut, sehingga dapat menjangkau pihak-pihak yang memerlukan, khususnya masyarakat tidak mampu. Harapan dengan telah diterapkannya aturan tersebut, dapat semakin meningkatkan kesadaran masyarakat untuk segera mendaftarkan tanahnya, sehingga apa yang menjadi cita-cita dari Pasal 9 ayat (1) UUPA dapat segera tercapai, yaitu terciptanya pendaftraan tanah di seluruh wilayah Indonesia. 


\section{DAFTAR PUSTAKA}

Hanitijo, Ronny, Soemitro, 1988, Metodologi Penelitian Dan Jurimetri, Jakarta, Ghalia

Harsono, Boedi, 2008, Hukum Agraria Indonesia, Sejarah Pembentukan UndangUndang Pokok Agraria Isi Dan Pelaksanaannya, Jakarta, Djambatan

Ibrahim, Johnny, 2006, Teori dan Metodologi Penelitian Hukum Normatif, Malang, Bayumedia Publishing

Murad, Rusmadi, 2013, Administrasi Pertanahan Pelaksanaan Hukum Pertanahan Dalam Praktek, Bandung, Mandar Maju

Santoso, Urip, 2012, Hukum Agraria Kajian Komprehensif, Jakarta, Kencana

Undang-Undang Nomor 5 Tahun 1960 tentang Undang-Undang Pokok Agraria

Peraturan Pemerintah Nomor 24 Tahun 1997 tentang Pendaftaran Tanah

Peraturan Pemerintah Nomor 13 Tahun 2010 tentang Jenis Dan Tarif Atas Jenis Penerimaan Negara Bukan Pajak yang berlaku pada Badan Pertanahan Nasional

Peraturan Pemerintah Nomor 128 Tahun 2015 tentang Jenis Dan Tarif Atas Jenis Penerimaan Negara Bukan Pajak Yang Berlaku Pada Kementerian Agraria Dan Tata Ruang/Badan Pertanahan Nasional

Prama Widianugraha, http://jurnal.fh.unpad.ac.id/index.php/jbmh/issue/archive, Tinjauan Normatif Pendaftaran Tanah Sistematis Lengkap Dikaitkan Pembentukan Aturan Peraturan Perundang-Undangan, Jurnal Bina Mulia Hukum, Volume 3, Nomor 2, Maret 2019 